\title{
Host Impact and Specificity of Tortoise Beetle (Cassida rubiginosa) on Canada Thistle (Cirsium arvense) in Iran
}

\author{
Ghorbanali Asadi, Reza Ghorbani, Javad Karimi, Alireza Bagheri, and Heinz Mueller-Schaerer*
}

\begin{abstract}
This study determined the potential of the tortoise beetle (Coleoptera: Chrysomelidae) to control Canada thistle (Asteraceae) in Iran. Genetic analysis of the tortoise beetle, based on mitochondrial DNA, confirmed the presence of the species in Iran. A field experiment using five insect densities ( 0 to 20 larvae plant ${ }^{-1}$ ) showed a positive correlation between the number of larvae transferred and impact. Feeding by 20 larvae reduced total biomass of Canada thistle by $78 \%$ and the number of capitula by $94 \%$. More important, when grown in competition with wheat, four and eight egg batches (corresponding to approximately 12 and 24 larvae) per Canada thistle plant increased wheat ear weight by 46 and $82 \%$, respectively. Host range studies with 22 crop and 21 weed species using no-choice and multiple-choice tests under laboratory and field conditions and parallel data from a field survey showed that joint feeding and oviposition were restricted to Canada thistle and a few other weed species. Limited feeding, without oviposition, was recorded on an additional seven weed species but also on safflower (10 to $15 \%$ reduction in biomass), and common sunflower $(<10 \%)$; the latter only under no-choice conditions. The growing period of either crop species, however, does not coincide with the feeding period of the tortoise beetle in the field. Findings indicate that the tortoise beetle is a promising biological control agent for Canada thistle in arable crops and grasslands in Iran. Other complementary methods will likely be needed to prevent substantial yield losses.

Nomenclature: tortoise beetle, Cassida rubiginosa Müller; Canada thistle, Cirsium arvense (L.) Scop.; common sunflower, Helianthus annuus L.; safflower, Carthamus tinctorius L.; wheat, Triticum aestivum L.

Key words: Biological weed control, herbivorous insects, host range test, integrated weed management, Iran, weed management, wheat.
\end{abstract}

\begin{abstract}
Este estudio determinó el potencial del escarabajo Cassida rubiginosa (Coleoptera: Chrysomelidae) para controlar Cirsium arvense (Asteraceae) en Irán. Análisis genéticos de C. rubiginosa, basados en ADN mitocondrial, confirmaron la presencia de esta especie en Irán. Un experimento de campo usando cinco densidades del insecto ( 0 a 20 larvas por planta) mostraron una correlación positiva entre el número de larvas transferidas y su impacto. La alimentación de las 20 larvas redujo la biomasa total de $C$. arvense en $78 \%$ y el número de capítulos florales en $94 \%$. Más importante aún, cuando la maleza creció en competencia con trigo, cuatro y ocho grupos de huevos (equivalentes a 12 a 24 larvas aproximadamente) por planta de C. arvense incrementaron el peso de la espiga del trigo en 46 a 82\%, respectivamente. Estudios de laboratorio y campo con 22 cultivos y 21 especies de malezas para determinar el rango de hospederos, usando pruebas sin alternativa o con alternativas múltiples y datos paralelos de estudios observacionales de campo, mostraron que la alimentación y la oviposición se limitó a $C$. arvense y unas pocas especies de malezas. Alimentación limitada, sin oviposición, se observó en siete especies de malezas adicionales y en cártamo (10 a 15\% reducción de biomasa) y en girasol (<10\%); y en este último caso solamente en condiciones sin alternativa. Sin embargo, el período de crecimiento para cualquiera de las especies de cultivos, no coincide con el período de alimentación de C. rubiginosa en el campo. Estos descubrimientos indican que $C$. rubiginosa es un agente promisorio de control biológico de $C$. arvense en cultivos arables y pastizales en Irán. Otros métodos complementarios serán posiblemente necesarios para prevenir pérdidas de rendimiento sustanciales.
\end{abstract}

Canada thistle (Asteraceae) is a noxious, perennial weed with a worldwide distribution that is especially problematic in North America and Europe (Alex 1966; Bourdot and Harvey 1996; Donald 1990; McLennan et al. 1991; Moore 1975; Morishita 1999; Skinner et al. 2000). The species is believed to have originated in the temperate Middle East, and its spread has closely followed human migration and agricultural activities (Tiley 2010). Its native range may include Europe;

* First, second, and fourth authors: Assistant Professor, Associate Professor, and Ph.D Student, Department of Agronomy, Faculty of Agriculture, Ferdowsi University of Mashhad, P.O. Box 91775-1163, Mashhad, Iran; third author: Assistant Professor, Department of Plant Protection, Faculty of Agriculture, Ferdowsi University of Mashhad, P.O. Box 91775-1163, Mashhad, Iran; fifth author: Professor, Département de Biologie/Ecologie et Evolution, Université de Fribourg, Pérolles, CH-1700 Fribourg, Switzerland. Corresponding author: E-mail: ghorbani43@gmail.com parts of North Africa; the eastern Mediterranean; southern Asia; Afghanistan, Iran, and Pakistan; and as far east as China (Van Driesche et al. 2002), but it is now thought to be naturalized worldwide. In Iran, it occurs in pastures and crop fields and is common in most provinces, including Gorgan, Mazendran, Zanjan, Hamadan, Lorestan, Khorasan, Tehran, Semnan, Azarbayejan, Isfahan, Fars, Sistan, Kerman, and Ghazvin (Rechýnger 1979), where it is considered a major agricultural weed.

The control of Canada thistle is most challenging because of its ability to reproduce both sexually and vegetatively. Its extensive and deep root system allows for high clonal regeneration (Kluth et al. 2001) and survival, even when aboveground shoots are removed (Moore 1975; Thomas et al. 1994). It is one of the most important perennial weeds in wheat fields of Iran, especially in areas where that crop is cultivated continuously for several years. The use of chemical 
control for Canada thistle is limited because of its taxonomic similarity to crops it infests or because the use of herbicides is restricted or prohibited in habitats such as ecological conservation areas or organic cropping systems (Tiley 2010). The use of biological control or natural enemies to reduce pest populations has repeatedly been suggested as a potential alternative method for managing this aggressive weed. However, this control tactic has yet to be successful under field conditions and as a single control measure (Demers et al. 2006; Ghosheh 2005; Hatcher and Melander 2003).

Biological control of weeds is based on the observation that antagonistic organisms can decrease the density and fitness of host plants (Cruttwell McFadyen 1998; Ghosheh 2005; Morin et al. 2009). Several pathogens and insects are reported to attack Canada thistle, and many have been evaluated for their potential as biological control agents, but none of the organisms tested have proven to be effective (Ang 1995; Collier et al. 2007; Hein and Wilson 2004; Kluth et al. 2005; Lalonde and Roitberg 1992; Maw 1976; Thomas et al. 1994; Tiley 2010; Wheeler and Whitehead 1985). Therefore, there is a need to determine additional biological control options for the management of this noxious thistle.

The leaf-feeding tortoise beetle (Coleoptera: Chrysomelidae) is native and widely distributed in the Palearctic region (Ward and Pienkowski 1978). The tortoise beetle is found in Europe, the United States, and Canada. It occurs throughout continental Europe from Fennoscandia south through the Baltic republics to Greece and Spain, Great Britain, and across Siberia to the northern Far East of Russia (Majka and Lesage 2008). The current distribution of the leaf-feeding tortoise beetle in Iran is not known, but in this region, it exhibits one generation with five instars and can reproduce sexually. Previous work has shown a strong detrimental effect of this beetle on the performance and survival of Canada thistle. For instance, when using 20 tortoise beetle larvae plant $^{-1}$ (introduced onto $12-$ to $15-\mathrm{cm}$ diam rosettes), less than one-third of Canada thistle plants survived at the end of the season (Ang 1995; Bacher and Schwab 2000). Based on hostspecificity feeding tests, tortoise beetle adults and larvae feed on several genera in the Asteraceae, including Arctium, Carduus, Cirsium, Silybum, Onopordum, and Centaurea, as well as globe artichoke (Cynara scolymus L.) (Kok 2001; Zwolfer 1969; Zwolfer and Eichhorn 1966). The host plant range and ecological impact of phytophagous insects on resident plant communities represents a major challenge for the deployment of biological control agents (Jordon-Thaden 2003). However, the main problem for successful control of Canada thistle has been to achieve sufficiently high numbers of tortoise beetles during the growing season. Long-term control of Canada thistle using the tortoise beetle may be achieved in a cropping system where the crop exerts an additional competitive effect on this target weed (Ang 1995). Bacher and Schwab (2000) showed that the combined effects of the tortoise beetle and plant competition in two vegetation types significantly reduced Canada thistle performance, whereas the beetle alone at natural densities resulted in no measurable effects.

Morphological characteristics alone cannot accurately be used to identify the tortoise beetle and thus, a molecular approach is needed (Armstrong and Ball 2005; Szalanski et al. 2000). Recently, sequence analyses of mitochondrial DNA (mtDNA) were used for diagnostic and phylogenetic analyses. Studies on mtDNA sequences are increasingly used to identify insects at the species level (Hebert et al. 2004). Among the mitochondrial genes, the cytochrome oxidase subunit 1 (COI) is currently used as the standard barcode region for several insect species (Anonymous 2006) and for phylogenetic analyses in insects (Eben and Espinosa De Los Monteros 2004). Consequently, molecular characterization can be used as a reliable diagnostic method to identify species and, furthermore, allows species identification of immature stages, where discriminating morphological features are often ambiguous.

The general objectives of our study were to investigate the potential of the tortoise beetle, newly described for Iran, to control Canada thistle in a wheat crop. For this beetle to be used in Iran, host-specificity tests need to be extended to include high-cash crops and closely related plants from Iran. The effectiveness of this candidate biological control agent also needs to be assessed under local climatic conditions. The specific objectives of this research were to determine (1) the nucleotide sequence of the $C O I$ of putative tortoise beetles collected from the northern Khorasan province of Iran for confirming the species identity, (2) effects of different tortoise beetle larval densities on Canada thistle vegetative growth and number of capitula produced, (3) the combined effects of tortoise beetle feeding and competition with wheat in the field on Canada thistle and wheat performance, and (4) the host range of the tortoise beetle as a biosafety measure when considering this potential biological control agent in Iran.

\section{Materials and Methods}

The study was carried out during 2007 and 2008 in an experimental field at the Shirvan College of Agriculture and Natural Resources, Ferdowsi University of Mashhad, Iran $\left(37^{\circ} 23^{\prime} 30^{\prime \prime} \mathrm{N}, 57^{\circ} 54^{\prime} 30^{\prime \prime} \mathrm{E}\right.$; altitude, 1,052 m above sea level). This site has a temperate, mountainous climate, but during summer months, especially in recent years, has a typically dry and relatively hot, semidesert climate, with average annual precipitation of $267 \mathrm{~mm}$ and temperatures up to $40 \mathrm{C}$. In contrast, winters are mild, with temperatures rarely falling to -10 C. Tortoise beetle adults and larvae used for the molecular analysis and all experiments were collected from infested fields in Shirvan, Iran, in April 2007 and 2008.

DNA Extraction, Polymerase Chain Reaction, and Sequence Analysis. Total genomic DNA was extracted from a single adult chrysomelid using the DNA easy blood and tissue kit (http://www.qiagen.com/default.aspx, September 28, 2011; QIAGEN GmbH, Hilden, Germany). A doublestranded COI template was generated using polymerase chain reaction (PCR) with universally conserved mtDNA COI primers (Simon et al. 1994). Each PCR reaction contained 3 $\mu \mathrm{l}$ DNA, $10 \mu \mathrm{l}$ Bioneer ready master mixtures (http://us. bioneer.com) and $0.3 \mu \mathrm{M}$ of each primer in a final volume of $20 \mu \mathrm{l}$ and was performed in a Biometra thermocycler. The PCR reaction program was 34 cycles of $94 \mathrm{C}$ for $1 \mathrm{~min}, 50 \mathrm{C}$ 
for $1 \mathrm{~min}$, and $72 \mathrm{C}$ for $1.5 \mathrm{~h}$, with a final extension of $72 \mathrm{C}$ for $6 \mathrm{~min}$. DNA fragments were electrophoresed in $1.5 \%$ agarose gel at $120 \mathrm{~V}$, for $2.5 \mathrm{~h}$ in Tris/borate/EDTA (TBE) buffer. PCR products were purified using Bioneer Corporation (Daejeon, South Korea) purification kit and sequences determined using BigDye 1.1 chemistry on an ABI 3100 automated sequencer (PE Applied Biosystems, Foster City, CA). To confirm the accuracy of results, DNA was sequenced in both forward and reverse directions. Sequences were checked and assembled using the ATGC program v. 4 (Genetyx Corporation, SDC Software Development Co., Ltd., Tokyo, Japan; http://genetyx-corporation.software. informer.com/, accessed: September 12, 2011) and BioEdit program (Hall 1999).

Host Impact Studies. The host impact tests were carried out in a field having a clay loamy soil that had been under a sugarbeet (Beta vulgaris )-wheat/barley (Hordeum vulgare L.) rotation during past $30 \mathrm{yr}$. The land was prepared by plowing and disking in mid-March and a 10 by $10-\mathrm{m}$ field area (100 $\mathrm{m}^{2}$ ) was then divided into 25 plots of $4 \mathrm{~m}^{2}$. Two Canada thistle root fragments with a diameter of 0.5 to $1 \mathrm{~cm}$ and two to three buds were collected from nearby fields on March 15 and transplanted on the same day at a soil depth of $20 \mathrm{~cm}$ and at a distance of $50 \mathrm{~cm}$ diagonally in each of the 25 plots. Transplants were irrigated immediately, and then, irrigation was repeated every $10 \mathrm{~d}$. Second instar tortoise beetle larvae were collected from naturally infested areas and transferred on young rosette plants at the three- to five-leaf stage in April 2007 and April 2008. Cages ( 40 by 40 by $80 \mathrm{~cm}$ height; metal frames with woven plastic mesh and $1-\mathrm{mm}$ mesh size) were placed over the plots to prevent movement of the larvae among plots. The experiment was a randomized completeblock design with five treatments, i.e., transferring $0,5,10$, 15 , or 20 second-instar larvae plant ${ }^{-1}$, with five replications per treatment (25 plots total). Previous studies by Bacher and Schwab (2000) in Switzerland showed that densities of up to 20 tortoise beetle larvae per thistle shoot can be maintained and can occur under field conditions. Such densities were also observed at our study site in Iran (G. Asadi, personal observation), but we expected significant negative impact on Canada thistle performance at lower densities. Larval survival and damage on plant shoots were recorded at regular intervals until August in both years. Plant heights (measured from soil surface to the longest shoot) were measured twice during the growing season, i.e., $20 \mathrm{~d}$ after larval transfer and before harvest. In mid-August of the first year (2007), plant height and the number of capitula per plant shoot were determined. Afterward, the entire shoot and roots of one randomly selected mature plant per plot was harvested, and fresh and dry weights of the roots and shoots were determined. The second Canada thistle plant in each plot was kept for the second year to assess overwintering survival, with plants harvested in mid-August 2008.

In April 2008, a wheat (variety 'Sayonz') field infested with Canada thistle was chosen to evaluate the effectiveness of the tortoise beetle on this weed when competing with wheat. Wheat production procedures on this grower field included plowing, disking, fertilization, and flooded irrigation. Urea at a rate of $100 \mathrm{~kg} \mathrm{ha}^{-1}$ was broadcast applied twice during spring and $150 \mathrm{~kg} \mathrm{ha}^{-1}$ of triple super phosphate was banded along the side of the furrow ridge in the fall. In general, no insecticides and herbicides were used in the experimental plots, although 2,4-D and tribenuron methyl and the insecticide phenitrition were applied in the commercial section of the same field.

In the wheat field, 16 young (four- to six-leaf stage) Canada thistle plants having different batches of tortoise beetle eggs and surrounded by 10 wheat plants were selected for study, and all other wheat and weed plants nearby were removed by hand. Four replicates of $0,4,8$, and 12 naturally oviposited egg batches of tortoise beetles per plant were maintained randomly on the 16 Canada thistle plants, with all other eggs removed. Each egg batch comprised four to five eggs and, on average, resulted in the production of three larvae. Each Canada thistle plant and its 10 surrounding wheat plants were covered with a cage (as described above). At the end of the experiment, on July 12, 2008, aboveground parts of all 16 Canada thistle target plants were harvested, and stem length, stem diameter, fresh weight, and number of Canada thistle capitula per plant were determined. Dry weight (biomass) was determined by oven-drying plants at $75 \mathrm{C}$ for $48 \mathrm{~h}$ and weighing. The number and dry weight of wheat ears were also recorded.

Host Range Studies. Host range studies for the tortoise beetle involved no-choice and multiple-choice experiments with 22 crop and 21 weed species (Table 1) studied in the laboratory (no-choice, detached leaf), greenhouse (no-choice, one threeto six-leaf plant per pot) and field (multiple-choice, using a single, large cage). The selected crop and weed species are the most important crops and associated weeds in the region. In laboratory studies, four adult tortoise beetles were released in four replicated plastic boxes $(9 \mathrm{~cm}$ diam by $2 \mathrm{~cm}$ depth) containing one detached leaf. In the greenhouse, each pot (30 $\mathrm{cm}$ diam and $30 \mathrm{~cm}$ depth) contained a three- to six true-leaf plant and four adult tortoise beetles. Pots were covered with a plastic mesh (1 $\mathrm{mm}$ diam) and feeding, survival, and oviposition recorded twice weekly for $5 \mathrm{wk}$. Laboratory and greenhouse experimental treatments were arranged in a completely randomized design with four replications. In the field study, one large cage ( 2 by 3 by $1 \mathrm{~m}$ high and made from the same material as that described above) was used, and two individuals of all crop and weed species assessed were planted in the cage. Twenty pairs of adult tortoise beetles were released in the cage on April 10, 2009. Feeding intensity (i.e., percentage of biomass removed), survival, and oviposition were recorded once weekly for 6 wk. In parallel, feeding and oviposition by tortoise beetles, naturally occurring at the site, were recorded for 20 individuals of each of the 21 weed species that were also assessed in the cage. Only plants at or before the flowering stage were used.

Statistical Analysis. Data were analyzed with ANOVA, and means were compared by using Fisher's Protected LSD test ( $\alpha$ $=0.05)$ (Steel and Torrie 1980). If necessary, data were arcsin or $\log _{10}(x+1)$ transformed before analyses to satisfy assumptions of ANOVA. The impact of larval density and the number of egg batches on the performance of Canada thistle and wheat were also analyzed by regression analysis. 
Table 1. Host-range test results for the tortoise beetle (Cassida rubiginosa), a potential biological control agent for Canada thistle in Iran. ${ }^{\text {a }}$

\begin{tabular}{|c|c|c|c|c|c|c|c|c|}
\hline Plant family & Crop & Experiment type & $\mathrm{F}$ & $\mathrm{O}$ & Weed species & Experiment type & $\mathrm{F}$ & $\mathrm{O}$ \\
\hline \multirow[t]{6}{*}{ Asteraceae } & Helianthus annuus & $\mathrm{dt}, \mathrm{PP}, \mathrm{fc}$ & $*$ & - & Carthamus sp. & NFS & $* *$ & + \\
\hline & Carthamus tinctorius & DT, PP, FC & ** & - & Acroptilon repens & NFS & $* *$ & + \\
\hline & & & & & Centaurea iberica & NFS & $* * *$ & + \\
\hline & & & & & Cirsium arvense & NFS & $* * *$ & + \\
\hline & & & & & Taraxacum syriacum & NFS & $*$ & - \\
\hline & & & & & Lactuca sp. & NFS & $*$ & - \\
\hline \multirow[t]{5}{*}{ Poaceae } & Triticum aestivum & $\mathrm{dt}, \mathrm{PP}, \mathrm{fc}$ & - & - & Hordeum sp. & $\mathrm{nfs}$ & - & - \\
\hline & Hordeum vulgaris & $\mathrm{dt}, \mathrm{PP}, \mathrm{fc}$ & - & - & Secale cereale $\mathrm{L}$. & $\mathrm{nfs}$ & - & - \\
\hline & Zea mays L. & $\mathrm{dt}, \mathrm{PP}, \mathrm{fc}$ & - & - & Avena ludoviciana Durieu & $\mathrm{nfs}$ & - & - \\
\hline & & & & & Hordeum spontaneum & $\mathrm{nfs}$ & - & - \\
\hline & & & & & Sorghum halepense (L.) Pers. & nfs & - & - \\
\hline \multirow[t]{3}{*}{ Brassicaceae } & Brassica rapa $\mathrm{L}$. & $\mathrm{dt}, \mathrm{PP}, \mathrm{fc}$ & - & - & Lepidium draba L. & NFS & $*$ & - \\
\hline & & & & & Lepidium latifolium & NFS & * & - \\
\hline & & & & & Rapistrum rugosum & NFS & * & - \\
\hline \multirow[t]{2}{*}{ Chenopodiaceae } & Beta vulgaris & $\mathrm{dt}, \mathrm{PP}, \mathrm{fc}$ & - & - & Chenopodium album & NFS & * & - \\
\hline & Spinacia oleracea L. & $\mathrm{dt}, \mathrm{PP}, \mathrm{fc}$ & - & - & Atriplex patula & NFS & $*$ & - \\
\hline \multirow[t]{14}{*}{ Others } & Phaseolus vulgaris $\mathrm{L}$. & $\mathrm{dt}, \mathrm{PP}, \mathrm{fc}$ & - & - & Amaranthus sp. & $\mathrm{nfs}$ & - & - \\
\hline & Cicer arietinum $\mathrm{L}$. & $\mathrm{dt}, \mathrm{PP}, \mathrm{fc}$ & - & - & Vicia violsa Roth & $\mathrm{nfs}$ & - & - \\
\hline & Medicago sativa $\mathrm{L}$. & $\mathrm{dt}, \mathrm{PP}, \mathrm{fc}$ & - & - & Polygonum aviculare $\mathrm{L}$. & $\mathrm{nfs}$ & - & - \\
\hline & Glycine $\max (\mathrm{L}$.$) Merr.$ & $\mathrm{dt}, \mathrm{PP}, \mathrm{fc}$ & - & - & Malva sp. & NFS & $*$ & - \\
\hline & Solanum melangona $\mathrm{L}$. & $\mathrm{dt}, \mathrm{PP}, \mathrm{fc}$ & - & - & Silene conoidea $\mathrm{L}$. & NFS & $*$ & - \\
\hline & Lycopersicon esculentum Mill. & $\mathrm{dt}, \mathrm{PP}, \mathrm{fc}$ & - & - & & & & \\
\hline & Capsicum frutescens $\mathrm{L}$. & $\mathrm{dt}, \mathrm{PP}, \mathrm{fc}$ & - & - & & & & \\
\hline & Solanum tuberosum L. & $\mathrm{dt}, \mathrm{PP}, \mathrm{fc}$ & - & - & & & & \\
\hline & Cucumis sativus & $\mathrm{dt}, \mathrm{PP}, \mathrm{fc}$ & - & - & & & & \\
\hline & Cucurbita sp. & $\mathrm{dt}, \mathrm{PP}, \mathrm{fc}$ & - & - & & & & \\
\hline & Cucumis melo L. & $\mathrm{dt}, \mathrm{PP}, \mathrm{fc}$ & - & - & & & & \\
\hline & Gossypium hirsutum L. & $\mathrm{dt}, \mathrm{PP}, \mathrm{fc}$ & - & - & & & & \\
\hline & Capsicum frutescens $\mathrm{L}$. & $\mathrm{dt}, \mathrm{PP}, \mathrm{fc}$ & - & - & & & & \\
\hline & Solanum tuberosum L. & $\mathrm{dt}, \mathrm{PP}, \mathrm{fc}$ & - & - & & & & \\
\hline
\end{tabular}

${ }^{\text {a }}$ Abbreviations: O, oviposition; -, not observed; +, observed; F, feeding (\% biomass reduction during 5 wk); - , no feeding; ${ }^{*}$, feeding $<10 \%$; ${ }^{*}$, feeding between 10 and $50 \%$; ${ }^{* *}$, feeding $>50 \%$; dt, detached leaves; pp, potted plants; fc, field cage; nfs, natural field survey. Capital letters indicate feeding or oviposition was observed.

For all analyses, the statistical package of Minitab version 13 (Minitab Inc., 2000, State College, PA) was used.

\section{Results and Discussion}

Molecular Characterization of Tortoise Beetle from Iran. The results of the multiple alignment showed that the COI sequence of the Iranian tortoise beetle clearly aligned with the sequence related to another sample of this species, without any gap. The sequence obtained was deposited in the GenBank database (National Center for Biotechnology information, Bethesda, MD) under accession number GQ910794. The nBLAST analysis further showed that the sequence in Iran has 97\% similarity to a tortoise beetle (accession AM283218) reported from the United States, the only record so far for the COI sequence of a tortoise beetle. By resolving the identity of the tortoise beetle using a classic molecular character, our study provides the first verified report of this species from Iran. The observed low divergence of only $0.2 \%$ and $1.5 \%$ between the tortoise beetle from Iran and Virginia indicates little interpopulation genetic diversity, but our record constitutes only the second published COI sequence of this species.

Host Impact on Individual Canada Thistle Plants. Our field study results indicate that feeding by the tortoise beetle significantly affected all performance traits of Canada thistle at the end of the first growing season. Canada thistle biomass was significantly reduced in all larval density treatments $(5$, 10, 15, and 20 larvae plant ${ }^{-1}$ ) compared with the control $(\mathrm{P} \leq 0.05)$. Total dry biomass decreased with increasing number of larvae from 5 to 20 (Figure $1 \mathrm{~A} ; y=45.647 e^{0.077 x}$, $\left.R^{2}=0.97\right)$. A large number of larvae (10 to 15 larvae plant ${ }^{-1}$ ) were needed for severe suppression of Canada thistle $(>70 \%$ biomass reduction), but even 5 larvae plant ${ }^{-1}$ significantly reduced biomass by about 40\% (Figure 1A). No plants died during the experiment.

The number of capitula per plant significantly decreased with increasing number of larvae transferred (Figure 1B; $y=$ $\left.72.82 e^{-0.139 x}, R^{2}=0.98\right)$. Percentage reduction in the number of capitula at 10,15, and 20 larvae plant ${ }^{-1}$ was 71,88 , and $94 \%$, respectively (Figure 1B). Twenty days after insect feeding and at the end of the growing season, the height of Canada thistle was significantly reduced (Figure 1C; $y=$ $\left.35.322 e^{-0.033 x}, R^{2}=0.98\right)$; however, at least 10 larvae plant $^{-1}$ were needed to cause a significant difference, compared with control plants, $20 \mathrm{~d}$ after transferring the larvae (Figure 1C). Moreover, 20 and $40 \%$ of plants with 15 and 20 larvae plant $^{-1}$, respectively, died during winter, whereas all control plants survived into the spring of the second year.

Although feeding by the tortoise beetle is restricted to leaves, reproduction of Canada thistle was also reduced. Increasing the number of insects per plant decreased the number of capitula by up to $97 \%$, and thus, a parallel reduction in seed output can be assumed even if the number of seeds per capitulum was not recorded in our study. This 

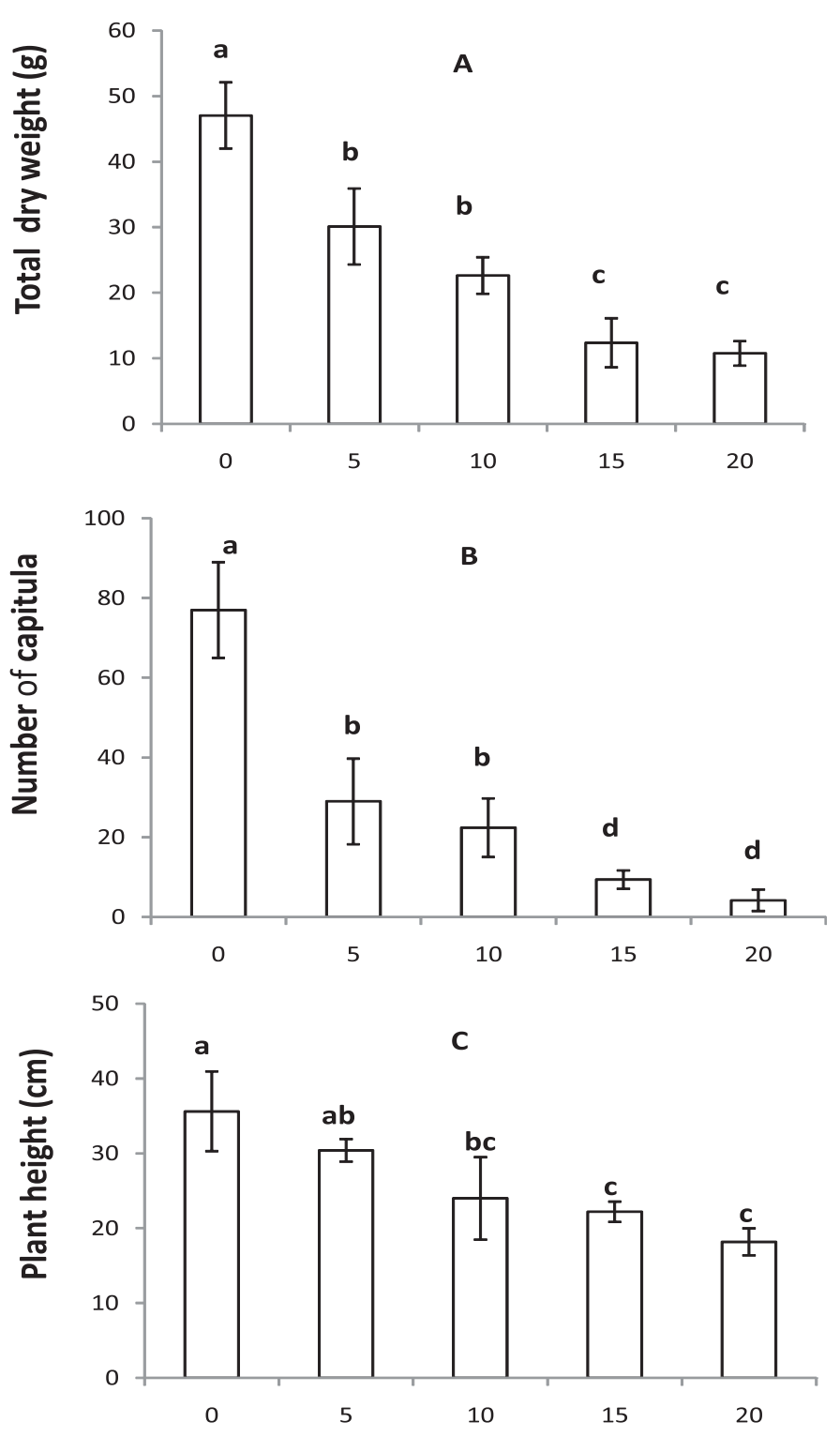

Number of larvae

Figure 1. Effect of Cassida rubiginosa larval density on performance of Canada thistle (A) biomass, (B) number of capitula, and (C) final plant height. Means (based on five replications) $\pm \mathrm{SE}$ are given. Means with different letters indicate significant differences $(\mathrm{P} \leq 0.05)$ according to Fisher's Protected LSD test.

insect feeds until the end of the growing season, imposing a cumulative negative effect on the performance of this weed. Reproductive organs were severely reduced (e.g., 88\% with 15 larvae plant $\left.{ }^{-1}\right)$ as a result of reductions in vegetative growth at the end of the growing season. Similar results were reported by Bacher and Schwab (2000) using the same number of insect larvae per plant. They also reported that $50 \%$ of Canada thistle plants died when subjected to feeding by 10 tortoise beetle larvae plant ${ }^{-1}$ and stated that using both competitor plants and tortoise beetles may successfully control Canada thistle. Ang (1995) also observed negative effects of tortoise beetle feeding on shoot biomass, but suggested that

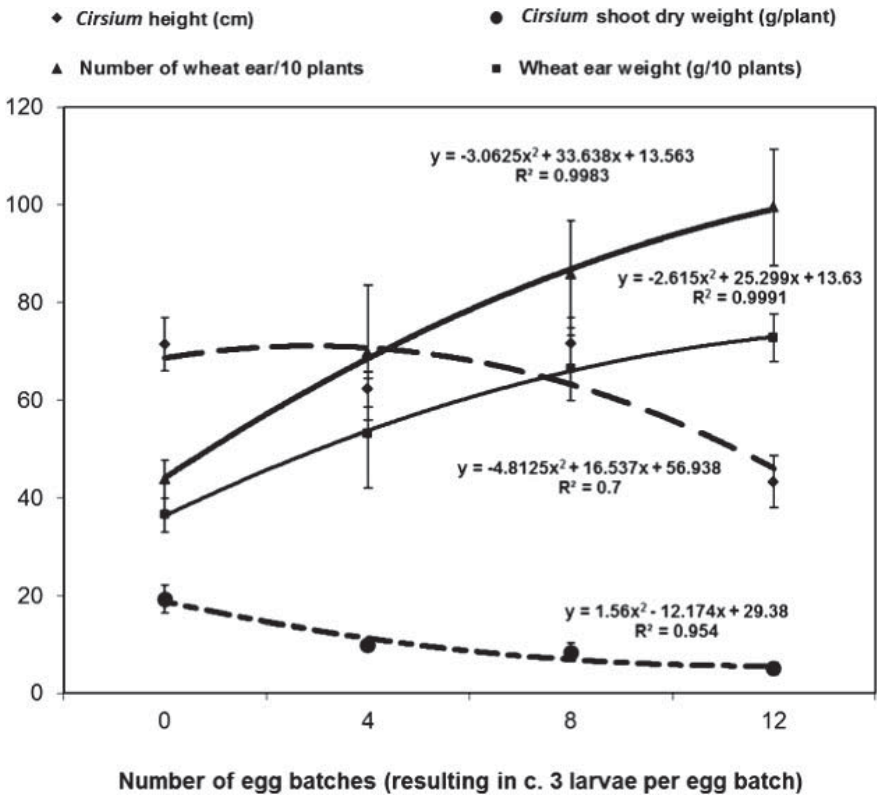

Figure 2. Relationship between the number of Cassida rubiginosa egg batches on the performance of Canada thistle and co-occurring wheat. Means (based on four replications) \pm SE are given. Key: $\diamond$, Canada thistle height; $\bullet$, Canada thistle shoot dry weight; $\boldsymbol{\Delta}$, Number of wheat ears; $\boldsymbol{\square}$, Wheat ear weight.

growth of secondary shoots after death of the primary shoot could explain the failure to reduce shoot density following feeding by beetles.

Combined Effects of Herbivory and Competition. In the field study, beetle attack reduced the biomass of Canada thistle grown with wheat. The number of egg batches per plant negatively affected Canada thistle height, shoot biomass, and number of capitula, resulting in a positive effect on the number and biomass of wheat ears (Figure 2). Increasing the number of tortoise beetle egg batches from 0 to 12 (corresponding to about 36 early instar larvae) caused a 40 and $75 \%$ reduction in Canada thistle height and biomass, respectively, and concomitantly doubled wheat ear biomass and increased wheat ear numbers by $227 \%$. Four egg batches (corresponding to about 12 larvae) on Canada thistle increased the number and weight of wheat ears by 60 and $45 \%$, respectively, as compared with Canada thistle plants receiving no beetle eggs. No plants died during the experiment.

In our study within a wheat field naturally infested with Canada thistle, the number of egg batches negatively affected Canada thistle height, shoot biomass, and number of capitula per plant (data not shown). The reduction in Canada thistle biomass increased performance parameters of wheat confirming field results of McLennan et al. (1991) and Harris (2003). The ability of tortoise beetles to negatively affect Canada thistle and alleviate crop-yield reductions is possible, especially when combined with additional abiotic stresses, such as severe cold, which occurred during the 2007 to 2008 winter. Although it may be difficult to extend individual plant damage to population level effects to achieve sustainable control (Müller-Schärer and Schaffner 2008), biological 
control agents that kill their host plant or reduce biomass and seed production may be important for achieving successful biological control when used alone or in combination with other control strategies. Combining biological control agents with competitive crops has been shown repeatedly to lead to successful weed control (Müller-Schärer 1991; Müller-Schärer et al. 2000).

Host Range Tests. In our host-range tests, joint feeding and oviposition by the tortoise beetle were observed only on Canada thistle, Iberian starthistle (Centaurea iberica Trev. ex Spreng.) and Russian knapweed [Acroptilon repens (L.) DC.] in the natural field survey (Table 1). Limited feeding, but no oviposition, was observed on several other weed species, including dandelion (Taraxacum officinale G.H. Weber ex Wiggers), wild lettuce (Lactuca spp.), hoary cress [Cardaria draba (L.) Desv.], perennial pepperweed (Lepidium latifolium L.), turnipweed [Rapistrum rugosum (L.) All.], common lambsquarters (Chenopodium album L.), halberdleaf orach (Atriplex patula L.), mallow (Malva L. sp.), and cone catchfly (Silene conoidea L.). No oviposition was observed on any of the tested crop species, but limited feeding $(<10 \%$ shoot removal) was recorded on common sunflower in no-choice tests using potted plants but not on detached leaves or in the field cage studies. Slightly more extended feeding (10 to 15\% shoot removal) was also observed in safflower in all tested conditions (Table 1). Thus, adult tortoise beetle females exhibited a clear oviposition preference for Canada thistle, with $>80 \%$ of all eggs deposited on this weed.

Our host range studies in 22 crops using both no-choice and multiple-choice tests and in 21 weed species through field experiments and surveys showed that joint feeding and oviposition by tortoise beetles were only observed on a few weed species, and only very limited feeding was recorded in no-choice treatments on safflower and common sunflower. Feeding on safflower was observed in all test conditions; however, no oviposition was recorded on safflower and common sunflower species, which is a positive feature of a safe biological control agent. This latter finding differs slightly from results of Reed et al. (2006), who found that although tortoise beetles fed on safflower in no-choice studies, no feeding was observed under field conditions. Feeding by the tortoise beetle is restricted to the months of April through June in northeastern Iran, when safflower and common sunflower plants are relatively young and the tortoise beetle has already completed oviposition on other plants in the region. Additional tests with rare and endangered (red-listed, IUCN, Gland, Switzerland) indigenous plants are, however, recommended. Based on our findings, we recommend continued research into the potential use of the tortoise beetle in Iran as a biological control agent against Canada thistle especially in arable crops and grassland ecosystems, including meadows, pastures, and natural grassland habitats, where plant competition is generally high.

The Way Forward. To achieve increased biological control impacts on Canada thistle, either (1) larval densities of the tortoise beetle have to be increased, or (2) this strategy needs to be combined with other management measures. To attain effective larval densities ( $>5$ larvae plant ${ }^{-1}$ ), mass production and release of tortoise beetles in an augmentative control strategy for Canada thistle (Müller-Schärer and Schaffner 2008) could be envisaged, but its economic feasibility needs to be carefully evaluated. Combinations with other antagonists (including pathogens) or cultural/mechanical management strategies have been investigated but would need to be locally adapted to be compatible with climatic conditions and agricultural practices of the region. There is evidence of a synergistic interaction between insect feeding and systemic infection by fungi, as fungus-infected thistles can exhibit higher attack rates from several ectophagous and endophagous insect species (Kluth et al. 2001), with some insects also capable of inducing systemic fungal infection (Friedli and Bacher 2001a,b). This research is currently underway.

\section{Acknowledgments}

We thank Sven Bacher, John Scott and Robin Collins for critically commenting on earlier versions of the manuscript, Antonio DiTommaso for editorial improvements, and the Ferdowsi University of Mashhad and the University of Fribourg for partial financial support.

\section{Literature Cited}

Alex, J. F. 1966. Survey of Weeds of Cultivated Land in the Prairie Provinces. Canada Agriculture. Regina, SK, Canada: Queen's Printer.

Ang, B. N. 1995. Canada thistle [Cirsium arvense (L.) Scop] response to density of Cassida rubiginosa Muller (Coleoptera: Chrysomelidae) and plant competition. Biol. Control 5:31-38.

Anonymous. 2006. Barcode of Life Database-BOLD. Washington, DC: National Museum of Natural History.

Armstrong, K. F. and S. L. Ball. 2005. DNA barcodes for biosecurity: Invasive species identification. Philos. Trans. R. Soc. Lond. B Biol. Sci. 360:18131823.

Bacher, S. and F. Schwab. 2000. Effect of herbivore density, timing of attack and plant community on performance of creeping thistle Cirsium arvense (L.) Scop. (Asteraceae). Biocontrol Sci. Technol. 10:343-352.

Bourdot, G. W. and I. C. Harvey. 1996. The potential of the fungus Sclerotinia sclerotiorum as a biological herbicide for controlling thistles in pasture. Plant Prot. Q. 11:259-262.

Collier, T. R., S. F. Enloe, J. K. Sciegienka, and F. D. Menalled. 2007. Combined impacts of Ceutorhynchus litura and herbicide treatments for Canada thistle suppression. Biol. Control 43:231-236.

Cruttwell McFadyen, R. E. 1998. Biological control of weeds. Ann. Rev. Entomol. 43:369-393.

Demers, A. M., D. K. Berner, and P. A. Backman. 2006. Enhancing incidence of Puccinia punctiformis, through mowing, to improve management of Canada thistle (Cirsium arvense). Biol. Control 39:481-488.

Donald, W. W. 1990. Management and control of Canada thistle (Cirsium arvense). Rev. Weed Sci. 5:193-250.

Eben, A. and A. Espinosa De Los Monteros. 2004. Ideas on the systematics of the genus Diabrotica Wilcox and other related leaf beetles. Pages 59-73 in P. Jolivet, J. A. Santiago-Blay, and M. Schmitt, eds. New Developments in the Biology of Chrysomelidae. Hague, Netherlands: SPB Academic.

Friedli, J. and S. Bacher. 2001a. Direct and indirect effects of a shoot-base boring weevil and plant competition on the performance of creeping thistle, Cirsium arvense. Biol. Control 22:219-226.

Friedli, J. and S. Bacher. 2001b. Mutualistic interaction between a shoot-base boring weevil and a rust fungus, two parasites of the weed creeping thistle. Oecologia 129:571-576

Ghosheh, H. Z. 2005. Constraints in implementing biological weed control: a review. Weed Biol. Manag. 5:83-92.

Hall, T. A. 1999. BioEdit: a user friendly biological sequence alignment editor and analysis program for Windows 95/98/NT. Pages 95-98 in Nucleic Acids Symposium Series 41. Oxford, UK: Oxford University Press. 
Harris, P. 2003. Classical Biological Control of Weeds Established Biocontrol Agent: Uphora cardui (L). Stem-Gall Fly. Ottawa, ON, Canada: Agriculture and Agri-Food Canada. 5 p.

Hatcher, P. E. and B. Melander. 2003. Combining physical, cultural and biological methods: Prospects for integrated non-chemical weed management strategies. Weed Res. 43:303-322.

Hebert, P.D.N., E. H. Penton, J. M. Burns, D. H. Janzen, and W. Hallwachs. 2004. Ten species in one: DNA barcoding reveals cryptic species in the neotropical skipper butterfly Astraptes fulgerator. Proc. Natl. Acad. Sci. U. S. A. 101:14812-14817.

Hein, G. L. and R. G. Wilson. 2004. Impact of Ceutorhynchus litura feeding on root carbohydrate levels in Canada thistle (Cirsium arvense). Weed Sci. 52:628-633.

Jordon-Thaden, I. E. 2003. Chemistry of Cirsium and Carduus: a role in ecological risk assessment for biological control of weeds? Biochem. Syst. Ecol. 31:1353-1396.

Kluth, S., A. Kruess, and T. Tscharntke. 2001. Interactions between the rust fungus Puccinia punctiformis and ectophagous and endophagous insects on creeping thistle. J. Appl. Ecol. 38:548-556.

Kluth, S., A. Kruess, and T. Tscharntke. 2005. Effects of two pathogens on the performance of Cirsium arvense in a successional fallow. Weed Res. 45:261269.

Kok, L. T. 2001. Classical biological control of nodding and plumeless thistles. Biol. Control 21:206-213.

Lalonde, R. G. and B. D. Roitberg. 1992. Field studies of seed predation in an introduced weedy thistle. Oikos 65:363-370.

Majka, C. G. and L. Lesage. 2008. Introduced leaf beetles of the Maritime Provinces, 7: Cassida rubiginosa Müller and Cassida flaveola Thunberg (Coleoptera: Chrysomelidae). Zootaxa 1811:37-56.

Maw, M. G. 1976. An annotated list of insects associated with Canada thistle (Cirsium arvense) in Canada. Can. Entomol. 108:235-244.

McLennan, B. R., R. Ashford, and M. D. Devine. 1991. Cirsium arvense (L.) Scop. competition with winter wheat (Triticum aestivum L.). Weed Res. 31:409-415.

Moore, R. J. 1975. The biology of Canadian weeds. 13. Cirsium arvense (L.) Scop. Can. J. Plant Sci. 55:1033-1048.

Morin, L., A. M. Reid, N. M. Sims-Chilton, Y. M. Buckley, K. Dhileepan, T. Hastwell, T. L. Nordblom, and S. Raghu. 2009. Review of approaches to evaluate the effectiveness of weed biological control agents. Biol. Control 51:1-15.

Morishita, D. W. 1999. Canada thistle. Pages 162-174 in R. L. Sheley and J. K. Petroff, eds. Biology and Management of Noxious Rangeland Weeds. Corvallis, OR: Oregon State University.

Müller-Schärer, H. 1991. The impact of root herbivory as a function of plant density and competition: survival, growth and fecundity of Centaurea maculosa (Compositae) in field plots. J. Appl. Ecol. 28:759-776.
Müller-Schärer, H. and U. Schaffner. 2008. Classical biological control: exploiting enemy escape to manage plant invasions. Biol. Invasions 10:859874.

Müller-Schärer, H., P. C. Scheepens, and M. P. Greaves. 2000. Biological control of weeds in European crops: recent achievements and future work. Weed Res. 40:83-98.

Rechýnger, K. H. 1979. Cirsium Adans. Pages 231-280. in K. H. Rechýnger, ed. Flora Iranica, Tomus 139a. Compositae III-Cynareae. Graz, Austria: Akademishe Druck-und-Verlansanstalt.

Reed, C. C., D. L. Larson, and J. L. Larson. 2006. Canada thistle biological control agents on two South Dakota wildlife refuges. Nat. Areas J. 26:47-52.

Simon, C., F. Frati, A. Beckenbach, B. Crespi, H. Liu, and P. Flook. 1994. Evolution, weighting, and phylogenetic utility of mitochondrial gene sequences and a compilation of conserved polymerase chain reaction primers. Ann. Entomol. Soc. Am. 87:651-701.

Skinner, K., L. Smith, and P. Rice. 2000. Using noxious weed lists to prioritize targets for developing weed management strategies. Weed Sci. 48:640-644.

Steel, R.G.D. and H. T. Torrie. 1980. Principles and Procedures of Statistics. New York: McGraw-Hill Book.

Szalanski, A. L., R. L. Roehrdanz, and D. B. Taylor. 2000. Genetic relationship among Diabrotica species (Coleoptera: Chrysomelidae) based on rDNA and mtDNA sequences. Fla. Entomol. 83:262-267.

Thomas, R. F., T. J. Tworkoski, R. C. French, and G. R. Leather. 1994. Puccinia punctiformis affects growth and reproduction of Canada thistle (Cirsium arvense). Weed Technol. 8:488-493.

Tiley, G.E.D. 2010. Biological flora of the British Isles: Cirsium arvense (L.) Scop. J. Ecol. 98:938-983.

Van Driesche, R. G., B. Blossey, M. Hoddle, S. Lyon, and R. Reardon, eds. 2002. Biological Control of Invasive Plants in the Eastern United States. Morgantown, WV: USDA Forest Service, FHTET-2002-04.

Ward, R. H. and R. L. Pienkowski. 1978. Biology of Cassida rubiginosa, a thistlefeeding shield beetle. Ann. Entomol. Soc. Am. 71:585-591.

Wheeler, A. G. and D. R. Whitehead. 1985. Larinus planus (F.) in North America (Coleoptera: Curculionidae: Cleoninae) and comments on biological control of Canada thistle. Proc. Entomol. Soc. Wash. 87:751-758.

Zwolfer, H. 1969. Experimental feeding ranges of species of Chrysomelidae (Col.) associated with Cynareae (Compositae) in Europe. Tech. Bull. Commonw. Inst. Biol. Control 12:115-130.

Zwolfer, H. and O. Eichhorn. 1966. The host ranges of Cassida spp. (Col. Chrysomelidae) attacking Cynareae (Compositae) in Europe. Z, Angew. Entomol. 58:384-397. 